\title{
THE PROBLEM OF IGNORANCE IN THE PHILOSOPHY OF AL-FARABI
}

\author{
${ }^{1}$ Rushanova Nelya, ${ }^{2}$ Syrgakbayeva Akmaral \\ Inelia_82@mail.ru'syrgakbaeva@mail.ru \\ Al-Farabi Kazakh National University (Almaty, Kazakhstan)
}

\author{
${ }^{1}$ Рушанова Неля Бериковна, ${ }^{2}$ Сыргакбаева Акмарал Салимжановна \\ Inelia82@mail.ru'2syrgakbaeva@mail.ru \\ Казахский национальный университет имени аль-Фараби \\ (Алматы, Казахстан)
}

\begin{abstract}
Al-Farabi devoted a significant part of his work to the development of social and ethical issues. The article attempts to reveal the content of the concept of "ignorance" in the heritage of al-Farabi. The need to raise this question is due to the fact that Farabi's philosophy is permeated with the understanding of the collisions of knowledge and ignorance, right and wrong in the attitude of people to each other and to the world around them. It can be argued without exaggeration that the concept of ignorance, in its various aspects, occupies a central place in the work of the Arab thinker and sets the scale and specifics of his social project. Ignorance in the interpretation of al-Farabi is primarily the opposite of virtue that is not only knowledge, education, but also a wrong view of life, of its values and goals. This wrong view gives rise to wrong actions, distorted morality, and with it - social relations that do not correspond to the concept of truly human.

Key words: al-Farabi, ethics, philosophy, culture, society, humanity, religious motives, ignorance.
\end{abstract}

\section{Introduction}

Al-Farabi devoted a significant part of his work to the development of social and ethical issues. At the same time, the importance of al-Farabi's legacy is determined by the fact that many of his ethical positions in the field of philosophy had a great influence on the subsequent development of world socio-philosophical thought. The Arab thinker, in his search for knowledge and truth, managed to overcome the existing ethno-cultural, linguistic and religious contradictions that existed before, during and after his era.

This article attempts to reveal the content of the concept of "ignorance" in the legacy of al-Farabi. The need to raise this question is due to the fact that Farabi's philosophy is literally permeated with the understanding of the collisions of knowledge and ignorance, right and wrong in the attitude of people to each other and to the world around them. It can be argued without exaggeration that the concept of ignorance, in its various aspects, occupies a central place in the work of the Arab thinker and sets the scale and specifics of his social project. 


\section{Methodology}

As for the research methodology, the article uses, firstly, textual analysis, which makes it possible to understand and clarify the meanings of the terms under study.

Secondly, in this study, it was required to move from abstract terms (formal logical concepts) to the concept of ignorance in its meaningful sense. This meant turning to the method of ascending from the abstract to the theoretically concrete.

Thirdly, it was very important for the disclosure of the topic of the article to turn to comparative analysis, which allows one to see transformations and stable meanings of the concept of ignorance. Across different cultures and philosophies, the concept of ignorance has unique characteristics and at the same time has universal meaning.

The problem of ignorance is deeply rooted and widespread in various philosophical systems.

So, in ancient Indian religious and philosophical thought, one of the key categories was precisely the category of ignorance. It was called "avidya" (avidyā), which literally means "lack of knowledge", "ignorance". It was not just about ignorance, which is characteristic of an uneducated individual who is not used to deep thinking and philosophical searches. Avidya was something akin to the "original sin" of the Abrahamic religion. Ignorance was considered ontologically the initial phenomenon (or, more precisely, the noumenon) of consciousness. Due to this phenomenon, the true essence of being was obscured and did not give in to true understanding. In Vedanta avidya (also called ajnana) was interpreted as an illusion determined by sensory perception and, accordingly, as a serious obstacle for a person who seeks liberation.

In the later era, the concept of ignorance took place in many philosophical and spiritual teachings. Even the Enlightenment project was nothing more than an attempt to overcome the ignorance of the people. This goal was presented to the classics of educational thought as a way to get rid of many social vices and problems.

In Kazakh culture, a critical consideration of the concept of "ignorance" played an important role in the philosophy of Abai. The concept of надандық (nanandyk) is encountered quite often in his works. Abai understands ignorance as ignorance of the correct worldview and as a consequent wrong way of life.

Al-Farabi developed similar ideas long before Abai. Ignorance in its interpretation is primarily the opposite of virtue. Of course, the thinker understands that virtue is brought up, among other things, on the basis of knowledge, a correct worldview. It is no coincidence that Farabi writes a lot about God and the world, about the properties of things and the human mind. He wants to get a complete picture of man and the world and convey this vision to the people who will create a virtuous city.

Thus, if we look at the problem of ignorance historically - from an earlier and from a later position, it is obvious that al-Farabi, speaking of ignorant cities, means not only knowledge, education. (Moreover, mass education sometimes leads to those "fruits of enlightenment" that were subjected to devastating artistic criticism by Leo Tolstoy.) For al-Farabi, ignorance is mainly a wrong view of life, its values and goals. A wrong view of the world and a person gives rise to wrong actions, distorted morality, and with it - social relations that do not correspond to the concept of truly human. 


\section{Social contexts of the concept of "ignorance" in the philosophy of al-Farabi}

It is here, in the system of social relations, that the center of al-Farabi's philosophy is located, it is here that his call for ethics, for the intellectual and moral improvement of man and society, sounds. In this regard, the philosophy and ideas of the thinker can become a valuable source of moral education for the younger generation.

Farabi puts forward the maxim that the goal of human activity is happiness. This goal can be achieved through rational knowledge. Al-Farabi creates the doctrine of the "virtuous city" based on the principles of Platonism, although the neo-Platonic and constructive elements of Aristotle's teachings should not be underestimated either.

In this regard, it is necessary to emphasize one curious point that is of significant importance: the ethical program of al-Farabi comments and develops Plato's ideas about the good in the light of the Muslim worldview, but the ethics of society is, first of all, the education of its citizens. In his "Treatise on the views of the inhabitants of a virtuous city" al-Farabi emphasizes: "By nature, each person is arranged in such a way that for his own existence and the achievement of the highest perfection he needs many things that he cannot provide himself alone and for the achievement of which he needs in a certain community of people, each individually delivering to him something from the totality of what he needs" [1, p. 303].

Al-Farabi also reflects on the vanity and transience of life, because everything in this world depends on time, everything is mobile, everything collapses under the power of time, everything flows into the abyss of the past, and the ticking of the clock speaks of this.

In the mind of the philosopher the irreversible movement of time turns into a moral criterion; this is the genesis of human ethics. All human actions become meaningful only over time. If a person is not aware of this ethical factor and his actions and motives have small features, he tries to deceive time and himself, and time turns into a thief - this is a metaphor for the illusion of the world. A person who does not relate to life without proper attention loses the very essence of life, its possible understanding and necessary experience. Man is a sliver floating in the stream of life. Such a person does not live his own life; everything passes, his whole life is effort, pressure, mechanicalness, rigid convention. His destiny is to relive the past as the world behind the wall, as something left unchanged. Time for him is a cumbersome rock; hours are converted into days, days into months, months into years and years into eras. When everything turns into an illusion, only ethics can save you from moral and psychological catastrophe.

Al-Farabi considers the structure of time to be similar to the structure of the Universe and includes the ethical nature of man. The functions of time are similar to those of ethics. Time heals and cripples, it heals or kills the body; but it also significantly affects the human soul. In "Pointing the Way to Happiness" the thinker likens the improvement of the disposition to the healing of the body [2, p. 20-21].

One of Farabi's works is dedicated to the difficult experiences of old age, the loneliness of an elderly person. Father and mother died many years ago, children have 
their own lives. Relatives with their problems and concerns are far from the old man; their life runs outside the ghostly wall of time, densely surrounding the old man with loneliness and a premonition of impending death. As before, they do not seek the support and sympathy of the old man, because he is involved in an invisible but inevitable process of decay. The old man wants to feel truly alive, he is trying to return to his former stormy life, but he is no longer strong. He tries to restore the fullness of the former perception of life, those years when energy was seething in him, when the body was strong and whole in its youth, but weakness extinguishes these attempts.

These trusting and sovereign impulses of the other world - resilience and powerlessness - are signs of irrational non-existence, their symbols and masks. Therefore, drowning in the ghosts of nothingness, the old man feels the ghost of life. Illusiveness is more meaningful than life, which is fading away. Therefore, everything for the old man loses its taste, the dream disappears - the main and constant companion of man. When the dream leaves him, he becomes lonely. He is overcome by fear of the future, ignorance of his future fate. Such ignorance is a person's prison, and memories and an inner voice are his executioners.

Happiness free from ignorance is a category that is at the center of al-Farabi's ethics. In a virtuous city, happiness, goodness, justice, inner and outer beauty are fulfilled. "A city in which the unity of people is aimed at mutual assistance in matters by which true happiness is obtained is a virtuous city, and a society where people help each other in order to achieve happiness is a virtuous society. The people, all of whose cities help each other in order to achieve happiness, are a virtuous people. In the same way, the whole earth will become virtuous if peoples help each other to achieve happiness" [1, p. 305].

This complex and universal baggage of ethical knowledge, deep compassion for people, understanding of the urgent need for change, understanding of the philosophy of the universe determined the reform activities of al-Farabi, his verified philosophical strategy. Such multifaceted personality parameters and his real work characterize al-Farabi as a unique personality in the history of the people, mark a new era of human life and show the need for a constructive response to new challenges of history. Al-Farabi felt this, he understood his exceptional and complex mission, so we see all the bitterness of the topic of ignorance in his philosophy, the expectation of the inevitable isolation of people from each other, their conflict with the environment and the breakdown of relations.

Ignorance as a social topic is extremely important for al-Farabi, it occupies a central place in his philosophy of ethics as a dominant thought that summarizes all meanings, all plans, all the nuances of his activities according to a certain humanistic program. His thoughts about the fate of people, the need for the development of science, technology and education, the struggle for a social future, for a way out of gloomy ignorance, tribal disunity and double oppression occupy the mind of the philosopher. These thoughts have become the main and constant in the life and work of the thinker, his emotional and moral aspirations inevitably return to this circle, sometimes taking shape in the doctrine of a pious person. Al-Farabi is an innovator who devoted his philosophy entirely to caring for the people and threw it from the abstract epic heavens to the long-suffering land. 
Al-Farabi's philosophy affects all aspects of existence, organizing the structure of the whole, revealing and shading the ethical discourse, setting the direction and tonality, interacting with the conceptual area of creating the entire architectonics of his thought. Farabi is the bearer of ethical consciousness. The volitional, mental, spiritual deeds of a philosopher, his inner world are of particular importance for creating a socio-historical and ethically significant context designed to influence the life of society. Al-Farabi revealed the world of man with his existential concerns, the ethical space of man, which reflects the phenomenon of life.

Al-Farabi approaches the problem of social ignorance and social virtue in a very specific way. In The Aphorisms of the Statesman, he points out: "The prudent man uses experience for his development and for his activities in the presence of the first chapter, when he exercises himself in virtuous politics, so that as a result of this he receives a very noble faculty useful in virtuous politics and reaches heights in management in the person of the one in whom virtuous management is inherent in the potency, until it is actualized $<$... The ability that is used in the lowest of the ignorant polities, namely in power-hungry polities, is lower and worse than anything that is used in all other places ...” [2, p. 259].

From this passage it becomes clear: al-Farabi looks to the future, realizing that today it is difficult to find an absolutely virtuous politics, since a person has not yet developed to the level of a virtuous person, i.e. man as such, in his true essence. People are still divided into clans, tribes, families, individuals, erecting boundaries among themselves.

Borders also lie in the religious sphere, although religion, according to al-Farabi, has its rightful place in society. According to him, religion is designed to guide members of society towards human excellence and thus, at the same time, contribute to the achievement of personal happiness and the well-being of the entire city. Therefore, according to Al-Farabi, religion is, in fact, a tool or craft intended for practical use; it cannot be regarded as a sphere of knowledge, wisdom and truth as such. This idea of religion and its place in society had a huge impact on subsequent thinkers of the Islamic world.

At first glance, the concept of al-Farabi's religion may seem somewhat belittling religion, especially from the point of view of existing confessions, such as, for example, Islam. The philosopher explicitly denies the status of religion as an autonomous field of knowledge and wisdom; he rejects its claim to exclusive truth and reduces it to a simple instrument. However, these features require their own specific context, namely an understanding of the main ontological and epistemological views of al-Farabi. In this respect, religion, spanning both doctrinal and legal branches, is the most important element in the governance of society. This is such an "enterprise" that should continue after the death of the first ruler, be encouraged and developed by subsequent rulers and those scientists who in a given society occupy a fairly high place in the natural hierarchy, being educated, erudite and responsible for the dissemination of knowledge necessary for happiness [3, pp. 173-178].

\section{Al-Farabi's ethical program and its modern connotations}

The concept of ignorance contains two meanings: ignorance (lack of knowledge) and impolite (lack of ethics). 
Al-Farabi's concept of "ignorance" is precisely a two-pronged phenomenon. The thinker interprets the spiritual world as the real ethical space of the subject of being, self-understanding and self-reflection of a person seeking and finding his identity in the infinity of the universe. It is a dramatic, even tragic existence of self-discovery and self-fixation in everyday life. In the morality of one person, the philosophy of the entire nation must make a breakthrough in development, denying the canons, destroying the old principles and forms, losing something, but at the same time finding a new space, a new ethics necessary for life. In the work of al-Farabi ethics is reflected as a tool of thinking, as a picture of the world and the fateful plan of life [4, p. 147].

Al-Farabi implicitly formulated a holistic ethical program. Sometimes with bitterness and sarcasm, he shows that the world should be connected with the living soul of a person, satisfy his moral expectations, express the nuances of his inner world and spiritual growth, as well as the dynamics of the world and cognition of the personality. Consequently, al-Farabi was the first to introduce into philosophy not an abstract anthropological principle of existence, but a personality, a person's inner world, where obvious ignorance is often present. Al-Farabi's philosophy is freed from ritual dogmas and canons, cleared of clichés and ethical schemes. This means that the surrounding world (freed from ignorance) was first seen and experienced as an object of inner beauty; it was mentally deciphered and reconstructed. The essence of objects and nature itself becomes a unique value in the philosophy of al-Farabi; it is the subject of a complete act of creation: the soul finds itself in the value center of the sensual, painful and self-conscious world. Such a meaningful semantic load of the objective world is explained by the strategy of conceptualizing and symbolizing the world as a special mental space in which one can actualize and reconstruct being and introduce a new beginning into space.

Conceptualization is a new principle of thinking introduced by al-Farabi into philosophy. It manifested a different level of thinking, a different type of symbolic generalization and hermeneutic concentration of meanings. Things figuratively represent life and indirectly reveal to us the soul of a person. The metaphor in al-Farabi's constructive schemes is associated with the conceptual field; it is an element of hidden but systematic relationships. Metaphors have a special semantic and mental load, they are the keys to the world of new large-scale concepts. The philosophy of metaphors, establishing a new level of thinking and knowledge, provokes reflexive analysis, draws a person's attention to his ignorance and acts as a stimulus, violating peace and illusory balance. And this is not accidental, because al-Farabi appears in the mental space as a critic, a destroyer of the foundations of the century, and at the same time as an organizer of new beginnings.

The concept of ignorance is also revealed through the political ideals of the thinker. This is most evident when comparing "virtuous" and "ignorant" cities. A virtuous city is ideal, while an ignorant city is a reality, but, according to al-Farabi, it gives some hope for improvement, if you engage in enlightenment, find a wise ruler. And even among the ignorant cities there are those that Farabi prefers because of the opportunity to turn them on the path of virtue. According to al-Farabi, in an ignorant city, people never strive for happiness, which is the highest spiritual perfection. The 
inhabitants of an ignorant city know only seeming benefits: health, wealth, pleasure, freedom to indulge in passions, honor and greatness.

Each of these benefits seems to the inhabitants of an ignorant city to be happiness, but the greatest happiness consists in the combination of all these benefits. The inhabitants of an ignorant city are limited to what is necessary for the existence of the body: food, drink, clothing, sexual intercourse. They help each other in achieving prosperity and wealth, considering them the goal of life [5, p. 95].

A virtuous city, according to al-Farabi, can exist thanks to a certain structural organization: on the basis of the ideas of education, moral purity and decency. The inhabitants of a virtuous city must strive for humanity and discipline that will enable them to be happy in both worlds. In other words, it means kinship and unity of the inhabitants of a virtuous city [6, p. 174-233].

In the philosophical system of al-Farabi, the central issue is the problem of man, his intellectual and moral perfection, his desire for freedom, personal and social happiness, his search for a better future. Al-Farabi is concerned about the origin and functioning of human society, the state, its types, forms of government, the role and place of law, the principles of a virtuous state, as well as the necessary qualities and attributes for a person endowed with power.

According to al-Farabi, human perfection is determined by the place of humanity in the cosmic order. Like any other inhabitant of the sublunary world, a person obeys the natural laws that determine bodily substances. However, unlike all other species belonging to the sphere of generation and decay, humans experience a certain influence of active intelligence. This active intelligence does not affect the human body, but rather its intelligence and imagination, the psychic abilities involved in thinking. This gives a person the ability and principle by which he can strive or independently achieve the rest of the perfection. Active intelligence and other separate types of intelligence constitute the perfection of humanity. It is they who help to avoid ignorance and impoliteness. When a person reaches this level of perfection, he attains a state of absolute happiness.

Al-Farabi reveals the motivational concept of society through science, education and human development. The philosopher focuses on this concept because it encourages society to cultivate spiritual and universal values. Indeed, culture can be imagined as a huge treasury in which universal and national values are created and preserved, all the achievements of human society from ancient times to the present day. All these values are the heritage of the culture of peoples. Therefore, it is important to start acquaintance with the national culture from its heritage. It is defined as a phenomenon of the spiritual life of people, their way of life, inherited and perceived from previous generations. Heritage is an essential foundation for building a new culture free of ignorance. The current generation is enriched by the experience of the past generation and passes on this experience to the future generation. This eternal process of trinity is open as long as people are alive.

The purpose of science is to analyze, comprehend and evaluate the ways of forming a person's spiritual potential. The creation of a spiritual society based on universal human benefits and national values is the responsibility of political leaders. For these pur- 
poses, a national idea is needed that strengthens the spiritual foundations and the highest goals of the ethnos. It includes the eradication of extreme poverty, the achievement of universal primary education and the improvement of maternal health [7, p.67-80].

The formation of a spiritual society is determined by exploring the paths based on science and values needed to implement measures aimed at ensuring social motivation. Despite maintaining high levels of literacy and academic achievement, the country's level of development requires new skills and a new way of thinking. Communication and knowledge are the driving force behind progress, improving the standard and quality of life. They provide people with new and reliable opportunities for development.

A nation that does not have full access to science deprives itself of the opportunity to avoid ignorance. Communication develops wealth and mentality. It associates with multicultural conditions in society and the formation of an air of trust. The fragmentation of the perception of the world, the nihilism of humanistic values and ideals, disappointment, the growth of various types of deviations are the negative consequences of this process. A reliable tool for preventing ignorance is the study of the true values of people, their spiritual foundations. Following the ideas of al-Farabi, it is important to find ways to optimize spirituality in order to visualize youth discourse as a separate social identity [8, p.111-118.].

In addition, as we have seen, Farabi introduces a temporal dimension into his philosophy, in particular, the characteristics of age-related changes and the corresponding perceptions. Therefore, we decided to reveal the position of students regarding ignorance and its influence on the life success of an individual. Were interviewed two hundred and sixty-eight students of all training courses of KazNU named after al-Farabi of eight specialties of the Faculty of Humanities. They had to answer the question: "What factors should be considered in order to avoid ignorance?" The results are shown in Table 1.

Table 1. Results of the answers of the Kazakhstani respondents: «What factors should be taken into consideration to avoid ignorance?»

\begin{tabular}{|l|c|c|c|c|}
\hline $\begin{array}{c}\text { The qualities } \\
\text { of the personality }\end{array}$ & First-year & Second-year & Third-year & Fourth-year \\
\hline The skills and talent & 5.0 & 7.7 & 41.94 & 17.4 \\
\hline Spiritual settings & 1.0 & 3.8 & 5.38 & 0 \\
\hline The ability to communicate & 8.0 & 2.5 & 10.75 & 21.7 \\
\hline The adaptable skills & 7.0 & 13.5 & 3.23 & 26.1 \\
\hline The luck and success & 10.0 & 1.9 & 4.3 & 4.3 \\
\hline The help of the parents & 3.0 & 3.8 & 2.15 & 0 \\
\hline The connections with necessary people & 23.0 & 19.2 & 9.68 & 0 \\
\hline Good education & 9.0 & 9.6 & 15.05 & 13.0 \\
\hline The diligence & 13.0 & 11.5 & 7.53 & 17.4 \\
\hline The computer literacy & 21.0 & 3.8 & 0 & 0 \\
\hline
\end{tabular}


Kazakhstani students are careful in formulating answers to the question about factors that help to avoid ignorance. They define the insignificant role of computer literacy, rather than spiritual values, as a guarantee of overcoming ignorance. It is obvious that the analysis of the spiritual attitudes of young people makes it possible to predict the directions of cultural development of the present and future society. Students realize that ignorance fills the mind with chaotic and distorted ideas, which complicates the process of full-fledged socialization and damages the cultural continuity of generations and the assimilation of traditional human values.

\section{Conclusions}

We found out that the concept of "ignorance" has two interrelated meanings. Ignorance is, firstly, ignorance (lack of knowledge) and, secondly, impoliteness (immorality). Al-Farabi's concept of ignorance implies the dual unity of these aspects of this phenomenon.

In the field of public life, ignorance, according to al-Farabi, manifests itself in ignorant politics as the opposite of virtuous politics. It is on this distinction that the thinker develops the concept of the virtuous city and the ignorant cities.

The way to move towards the most profound explanation of the responsibilities of mankind arising from its natural data and social essence is the unity of philosophy and religion, rationality and spirituality.

From the above description, we can conclude that the intellectual legacy of al-Farabi is the legacy of rationality and spirituality, uniting people and creating a stepping stone for the future. This is due to the fact that his philosophical tradition is becoming an environment for constructive philosophical dialogue, which should be appreciated in the current context with its own challenges and problems.

\section{List of references}

1. Аль-Фараби, Философские трактаты. - Алма-Ата: «Наука» Казахской ССР, 1970. $-425 \mathrm{c}$.

2. Аль-Фараби, Социально-этические трактаты. - Алма-Ата: «Наука» Казахской CCP, 1973. $-400 \mathrm{c}$.

3. Çevik M., Farabi's Utopia and Its Eschatological Relations, Journal of Islamic Research, 3 (2), 2010. P.173-178.

4. Griffel F., Al-Ghazālī’s Philosophical Theology, Oxford et al.: Oxford University Press, 2009. - P. 423

5. Касымжанов Х., Әбу Насыр Әл-Фараби. - Алматы, 1997. - 127 с.

6. Mehmet Bajrakdar, Isljam felsefesine girish. - Ankara: Turkie, 2017. - P.313.

7. Wiyono, M. Pemikiran Filsafat Al-Farabi, Substantia, vol. 18, no. 1, 2016, P. 67-80.

8. Бекжанова Ж., Построение типологии молодежного дискурса на основе анализа аутентичных языковых источников. Журнал языка и литературы, Том 6. № 2, 2015, С.111-118.

\section{Transliteration}

1. Al'-Farabi, Filosofskie traktaty [Philosophical Treatises]. - Alma-Ata: «Nauka» Kazahskoj SSR, 1970. $-425 \mathrm{~s}$. 
2. Al'-Farabi, Social'no-jeticheskie traktaty [Social and Ethic Treatises]. - Alma-Ata: «Nauka» Kazahskoj SSR, 1973. - 400 s.

3. Çevik M., Farabi’s Utopia and Its Eschatological Relations, Journal of Islamic Research, 3 (2), 2010. P.173-178.

4. Griffel F., Al-Ghazālı̄’s Philosophical Theology, Oxford et al.: Oxford University Press, 2009. - P. 423

5. Kasymzhanov H., Obu Nasyr Ol-Farabi [Abu Nasr al-Farabi]. - Almaty, 1997. - 127 c.

6. Mehmet Bajrakdar, Isljam felsefesine girish. - Ankara: Turkie, 2017. - P.313.

7. Wiyono, M. Pemikiran Filsafat Al-Farabi, Substantia, vol. 18, no. 1, 2016, P. 67-80.

8. Bekzhanova Zh., Postroenie tipologii molodezhnogo diskursa na osnove analiza autentichnyh jazykovyh istochnikov [Constructing Typology of youth Discourse Based on the Analysis of Authentic Language Sources]. Zhurnal jazyka i literatury, Tom 6. № 2, 2015, C.111-118.

\section{Рушанова Н.Б., Сыргакбаева А.С.}

Проблема невежества в философии аль-Фараби

Аннотация. Аль-Фараби посвятил значительную часть своей работы развитию социальных и этических вопросов. В статье делается попытка раскрыть содержание понятия «невежество» в наследии аль-Фараби. Необходимость поднять этот вопрос обусловлена тем, что философия Фараби пронизана пониманием коллизий знания и невежества, правильного и неправильного в отношении людей друг к другу и к окружающему миру. Можно без преувеличения утверждать, что концепция невежества в различных ее аспектах занимает центральное место в творчестве мыслителя и определяет масштаб и специфику его социального проекта. Невежество в трактовке аль-Фараби - это, прежде всего, противоположность добродетели, то есть не только знания, образование, но и неправильный взгляд на жизнь, на ее ценности и цели. Этот неправильный взгляд порождает неправильные действия, искаженную мораль, а вместе с ней и социальные отношения, не соответствующие концепции истинно человеческого.

Ключевые слова: аль-Фараби, этика, философия, культура, общество, человечество, религиозные мотивы, невежество.

\section{Рушанова Н.Б., Сыргакбаева А.С.}

\section{Әл-Фараби философиясындағы надандық мәселесі}

Аңдатnа. Әл-Фараби өзжұмысының едәуір бөлігін әлеуметтік-этикалық мәселелерді дамытуға арнады. Мақала әл-Фараби мұрасындағы «надандық» ұғымының мазмұнын ашуға тырысады. Бұл мәселені шешудегі қажеттілік Фараби философиясында білім мен надандықтың, адамдардың бір-біріне және қоршаған әлемге деген қатынасындағы дұрыс және бұрыс жақтарын қарастыруымен байланысты. Надандық ұғымы әртүрлі аспектілерде ойшыл шығармашылығында басты орын алады және оның әлеуметтік жобасының ауқымы мен ерекшеліктерін белгілейді деп асыра сілтемей айтуға болады. Әл-Фарабидің түсіндірмесіндегі надандық ұғымы, ең алдымен, ізгілікке қарама-қарсы қоя отырып, оны тек білім, ілім ғана емес, сонымен қатар өмірге, оның құндылықтары мен мақсаттарына деген дұрыс емес көзқарас. Бұл дұрыс емес көзқарас дұрыс емес әрекеттерді, бұрмаланған моральды, және шынайы адамзат концепциясына сәйкес келмейтін, қоғамдық қатынастарды тудырады.

Tүйін сөздер: әл-Фараби, этика, философия, мәдениет, қоғам, адамзат, діни себептер, надандық. 